\title{
ДОСЛІДЖЕННЯ ВПЛИВУ ЛІКУВАЛЬНОГО МАСАЖУ ВОЛОСИСТОЇ ЧАСТИНИ ГОЛОВИ 3 ЕФІРНИМИ ОЛІЯМИ НА РІСТ ВОЛОССЯ
}

\author{
О. Є. Качанов, О. М. Олещук \\ Харківський медичний коледж \\ ДВНЗ «Тернопільський державний медичний університет \\ імені І. Я. Горбачевського МОЗ Украйни" \\ ННІ медсестринства
}

\begin{abstract}
Наведено результати експериментальних досліджень та порівняльний аналіз отриманих результатів, що підтверджують збільшення об'єму волосистої частини голови на 29,1 \% після проведення лікувального масажу волосистої частини голови без використання ефірних олій та на 40,5\% - 3 ефірними оліями.
\end{abstract}

\section{RESEARCH OF INFLUENCE OF THERAPEUTIC MASSAGE THE SCALP WITH ESSENTIAL OILS ON HAIR GROWTH}

\author{
O. Ye. Kachanov, O. M. Oleshchuk \\ Kharkiv Medical College \\ SHEI «Ternopil State Medical University by I. Ya. Horbachevsky of MPH of Ukraine» \\ Educational and Scientific Institute of Nursing
}

\begin{abstract}
The experimental results and comparative analysis of the results, that confirm increase in volume of the scalp by $29.1 \%$ after a therapeutic massage the scalp without the use of essential oils and $40.5 \%$ - with essential oils.
\end{abstract}

Вступ. В останні десятиліття лікарі-дерматологи нашої країни відмічають значне зростання кількості пацієнтів на таке захворювання волосистої частини голови, як алопеція [1]. До сьогодні немає чіткого розуміння механізмів виникнення та розвитку цієї патології. Протягом останніх двадцяти років проводять наукові дослідження механізмів, що лежать в основі розладів росту волосся. Вважається, що, окрім гормональних розладів, основними факторами, що призводять до втрати волосся, $є$ спадковість і стреси. Облисіння може також виникати внаслідок опромінення, як результат побічної дії лікарських засобів, у тому числі й при хіміотерапії [2].

Враховуючи вищезазначене, пошук методів стимуляції появи нового та покращення стану існуючого волосся із застосуванням фізіотерапевтич- них методів впливу є актуальним у трибології та косметологіі. Тому актуальність проведених нами досліджень є очевидною.

Основна частина. Метою даного дослідження було вивчення впливу лікувального масажу волосистої частини голови з ефірними оліями та без них на ріст волосся. Лікувальний масаж проводився за методикою, наведеною в попередній нашій роботі [3].

У даному дослідженні проаналізовано результати опитування, обстеження та лабораторного дослідження (трихоскопії) 18 пацієнтів із дифузною алопецією. Усі пацієнти звернулися до лікаря зі скаргами на недостатній об'єм волосся, його випадання, або значну втрату волосся. Усі пацієнти - жіночої статі, що свідчить про те, що проблема облисіння має виражену статеву схильність.

(C) О. Є. Качанов, О.М. Опещук, 2014 
У всіх пацієнтів, які брали участь в дослідженні, було встановлено основний діагноз - дифузна алопеція. Деякі пацієнти страждали від таких супутніх захворювань, як остеохондроз шийного відділу хребта (ОШВ) (28\%), вегетосудинна дистонія (ВСД) $(59,5 \%)$, артеріальна гіпертензія (АГ) $(12,5 \%)$. Перенесені захворювання, такі, як гастрит, дискінезія жовчовивідних шляхів (ДЖВШ), цистит та інші, мали 55 \% пацієнтів.

Усіх пацієнтів було поділено на три групи по 6 чоловік у кожній:

- група A - особи, яким не проводився лікувальний масаж;

- група Б - особи, яким проводився лікувальний масаж вопосистої частини голови;

- група В - особи, яким проводився лікувальний масаж волосистої частини голови з ефірними оліями.

Пацієнти усіх трьох груп як базисну терапію приймали пікарський засіб «Пантагар» фірми Мерц Фарма ГмбХ, Німеччина.

Отримані результати піддавали статистичній обробці загальноприйнятими методами за програмою Microsoft Excell та з використанням t-критерію Стьюдента при $\mathrm{p} \leq 0,05$.

Пацієнти, які брали участь у дослідженні, за кольором шкіри належали до чотирьох основних типів, найпоширеніших у нашій країні [4], а саме:

Тип 1 - особи зі світлою, веснянкуватою шкірою, зазвичай рудоволосі або блондини. Шкіра типова для англосаксів. Ніколи не засмагає, миттєво обгорає.

Тип 2 - особи з блідим кольором шкіри. Звичайна шкіра середнього європейця зі світлим волоссям. Засмагає погано, легко обгорає.

Тип 3 - особи зі шкірою нейтрального кольору. Північноєвропейський тип з темно-русявим волоссям, добре засмагає, обгорає рідко.

Тип 4 - особи зі шкірою маслинового кольору. Середземноморський тип з темно-русявим волоссям. Легко засмагає та лише зрідка обгорає.

Результати опитувань та статистичний аналіз деяких показників наведено у трьох таблицях, відповідно до груп пацієнтів.

У ході опитування було виявлено такі спільні відомості про усіх 18 пацієнтів, які брали участь в дослідженні.

1. Щодо анамнезу життя:

- розвиток у дитинстві в межах норми;

- належні умови праці та побуту;

- ендокринологічні захворювання відсутні;
- алергологічний анамнез - не обтяжений;

- акушерський анамнез - не обтяжений.

2. Щодо анамнезу захворювання - всі пацієнти пов'язують початок хвороби та ії загострення зі стресами на роботі чи у сімейному житті.

3. Попереднє лікування дифузної алопеції не проводилося.

4. Об'єктивне обстеження:

- загальний стан хворого - задовільний;

- потовиділення та саловиділення в межах норми;

- стан волосся та нігтів - задовільний;

- слизові оболонки та підшкірна жирова клітковина в межах норми.

Опитування пацієнтів, у яких супутній діагноз був вегетосудинна дистонія чи остеохондроз шийного відділу хребта та які страждали від частого головного болю показало, що застосування лікувального масажу привело до зменшення випадків появи головного болю, а у деяких випадках аж до повного його зникнення після проходження курсу масажу волосистої частини голови (табл. 1-3).

Наявність шкідливих звичок, а саме куріння, виявлено у 2 пацієнтів кожної групи, що становить 33,3 \% від загальної кількості хворих. Оскільки розподіл пацієнтів зі шкідливими звичками був однаковим у кожній з досліджуваних груп пацієнтів, можна вважати, що цей показник не мав суттєвого впливу на результати лікування.

Проведений нами порівняльний аналіз отриманих результатів (табл. 4) показав, що розподіл пацієнтів у межах груп щодо віку, маси, зросту, тривалості захворювання достовірно не відрізнявся. Так, вік пацієнтів (у роках) групи А становив $(34,2 \pm 5,4)$, групи Б - $(34,2 \pm 5,4)$, групи В $(32,8 \pm 7,4)$. Середня маса пацієнтів (в кг) другої групи була найменшою і становила $(60,2 \pm 6,0)$, найбільшою $(68,8 \pm 6,0)$ у першій групі, а в третій $-(63,7 \pm 5,0)$, разом із тим різниця між показниками досліджуваних груп не була достовірною $(p>0,1)$. Щодо тривалості захворювання, яка також може впливати на ефективність проведеної терапії, то, в середньому пацієнти усіх груп страждали від алопеції дещо більше 2 років. Таким чином, можна вважати, що такі показники, як вік, маса та тривалість хворобибули однаковими в усіх досліджуваних групах. Зріст пацієнтів (у см) коливався від $(159,8 \pm 4,8)$ в пацієнтів групи Б до $(164,5 \pm 2,6)$ - у групі А.

Нами було встановлено (табл. 5), що кількість волосин, за результатами трихоскопії при застосуванні масажу в потиличній ділянці, зросла на 
$30,6 \%$, а у тім'яній на $36,0 \%$, а із застосуванням ефірних олій - 35,2 та 39,2\%, відповідно, порівняно $з$ групою А, та спостерігалася виражена тенденція до зростання порівняно з групою Б. Таким чином, приріст волосин в тім'яній та потиличній ділянках у групі А становив 5,7 та 5,7\%, у групі Б 34,1 та $35,5 \%$, у групі B - 46,2 та 46,1\%. Отже, загальне середнє значення приросту волосся, склало 5,$7 ; 34,7$ та 46,15\%, відповідно, до досліджуваних груп.

Таким чином, результати наших досліджень показали, збільшення об'єму волосистої частини голови на 29, 1 \% після проведення лікувального масажу волосистої частини голови без використання ефірних олій та на 40,5 \% - з ефірними оліями.

\section{Таблиця 1. Результати обстеження пацієнтів, які пройшли күрс лікування без масажу}

\begin{tabular}{|c|c|c|c|c|c|c|c|}
\hline 1. & Пацієнт & 1 & 2 & 3 & 4 & 5 & 6 \\
\hline 2. & Вік (роки) & 32 & 28 & 19 & 45 & 29 & 52 \\
\hline 3. & Maca (кг) & 78 & 55 & 61 & 55 & 70 & 88 \\
\hline 4. & 3ріст (см) & 169 & 165 & 160 & 170 & 155 & 168 \\
\hline 5. & $\begin{array}{l}\text { Супутній клінічний } \\
\text { діагноз }\end{array}$ & ОШВ & ВСД & ВСД & ОШВ & ВСД & ВСД \\
\hline 6. & \multicolumn{7}{|c|}{ Анамнез захворювання (Anamnesis morbi): } \\
\hline a) & $\begin{array}{l}\text { Тривалість } \\
\text { захворювання (роки) }\end{array}$ & 2 & 3 & 0,5 & 4 & 0,58 & 6 \\
\hline б) & Динаміка процесу & Повільна & Повільна & Різка & Поступова & Різка & Поступова \\
\hline 7. & \multicolumn{7}{|c|}{ Анамнез життя (Anamnesis vitae): } \\
\hline a) & Спадковість & \begin{tabular}{|l} 
Не \\
обтяжена \\
\end{tabular} & $\begin{array}{l}\text { Не } \\
\text { обтяжена }\end{array}$ & $\begin{array}{l}\text { Не } \\
\text { обтяжена }\end{array}$ & $\begin{array}{l}\text { Не } \\
\text { обтяжена }\end{array}$ & $\begin{array}{l}\text { Не } \\
\text { обтяжена }\end{array}$ & $\begin{array}{l}\text { Не } \\
\text { обтяжена }\end{array}$ \\
\hline б) & Трудове життя & Напружене & Напружене & Нормальне & Напружене & Напружене & Нормальне \\
\hline в) & $\begin{array}{l}\text { Перенесені } \\
\text { захворювання }\end{array}$ & Немас & Гастрит & Немас & ГРВI & Немас & Краснуха \\
\hline г) & Шкідливі звички & Відсутні & Відсутні & Куріння & Куріння & Відсутні & Відсутні \\
\hline 8. & \multicolumn{7}{|c|}{ Об’єктивне обстеження (Status praesens objectivus) стану шкіри поза вогнищами ураження: } \\
\hline a) & Тургор & Нормальний & Підвищений & Підвищений & Нормальний & Підвищений & Знижений \\
\hline б) & Тип кольору шкіри & 3 & 1 & 4 & 2 & 2 & 3 \\
\hline 9. & \multicolumn{7}{|c|}{ Локальний статус (Status localis): } \\
\hline a) & Характер ураження & Хронічний & Хронічний & Підгострий & Підгострий & Гострий & Дистрофічни \\
\hline 6) & $\begin{array}{l}\text { Частина ділянки } \\
\text { ураження }\end{array}$ & Багато & Багато & Поодинока & Поодинока & $\begin{array}{l}\text { Одне } \\
\text { вогнище }\end{array}$ & Багато \\
\hline в) & $\begin{array}{l}\text { Локалізація вогнищ у } \\
\text { ділянках уражень }\end{array}$ & $\begin{array}{l}\text { Потилична, } \\
\text { скронева }\end{array}$ & $\begin{array}{l}\text { Лобна, } \\
\text { потилична, } \\
\text { скронева }\end{array}$ & $\begin{array}{l}\text { Тім'яна, } \\
\text { скронева }\end{array}$ & $\begin{array}{l}\text { Верхня } \\
\text { тім'яна }\end{array}$ & Тім'яна & $\begin{array}{l}\text { Лобна, } \\
\text { тім'яна, } \\
\text { потилична, } \\
\text { скронева } \\
\end{array}$ \\
\hline г) & $\begin{array}{l}\text { Симетричність } \\
\text { ураження }\end{array}$ & Симетричне & Симетричне & Симетричне & Асиметричне & Асиметричне & Симетричне \\
\hline 10. & \multicolumn{7}{|c|}{ Результати трихоскопії тім'яної та потиличної ділянок: } \\
\hline a) & До базис терапії & \begin{tabular}{|l|l|}
$189 / 197$ \\
\end{tabular} & $211 / 232$ & $211 / 246$ & $269 / 261$ & $239 / 248$ & $170 / 175$ \\
\hline б) & Після базис терапії & $206 / 217$ & $229 / 247$ & $217 / 251$ & $279 / 275$ & $251 / 257$ & $181 / 189$ \\
\hline 11 & $\begin{array}{l}\text { Об'єктивні зміни } \\
\text { після проведеного } \\
\text { лікування }\end{array}$ & $\begin{array}{l}\text { Поява } \\
\text { поодиноких } \\
\text { пушкових } \\
\text { волосин } \\
\end{array}$ & $\begin{array}{l}\text { Відсутність } \\
\text { змін }\end{array}$ & $\begin{array}{l}\text { Відсутність } \\
\text { змін }\end{array}$ & $\begin{array}{l}\text { Відсутність } \\
\text { змін }\end{array}$ & $\begin{array}{l}\text { Поява } \\
\text { поодиноких } \\
\text { пушкових } \\
\text { волосин } \\
\end{array}$ & $\begin{array}{l}\text { Відсутність } \\
\text { змін }\end{array}$ \\
\hline 12 & $\begin{array}{l}\text { Суб’єктивний стан } \\
\text { пацієнта після } \\
\text { проведених процедур }\end{array}$ & $\begin{array}{l}\text { Незначне } \\
\text { покращення }\end{array}$ & $\begin{array}{l}\text { Відсутність } \\
\text { змін }\end{array}$ & $\begin{array}{l}\text { Відсутність } \\
\text { Змін }\end{array}$ & $\begin{array}{l}\text { Відсутність } \\
\text { змін }\end{array}$ & $\begin{array}{l}\text { Незначне } \\
\text { покращення }\end{array}$ & $\begin{array}{l}\text { Відсутність } \\
\text { Змін }\end{array}$ \\
\hline
\end{tabular}


Таблиця 2. Результати обстеження пацієнтів, які пройшли күрс базової терапії ү поєднанні 3 лікувальним масажем

\begin{tabular}{|c|c|c|c|c|c|c|c|}
\hline 1. & Пацієнт & 1 & 2 & 3 & 4 & 5 & 6 \\
\hline 2. & Вік (роки) & 29 & 36 & 38 & 26 & 20 & 47 \\
\hline 3. & Maca (кг) & 47 & 60 & 70 & 45 & 59 & 80 \\
\hline 4. & Зріст (см) & 153 & 165 & 156 & 150 & 179 & 156 \\
\hline 5. & $\begin{array}{l}\text { Супутній } \\
\text { клінічний } \\
\text { діагно3 }\end{array}$ & ОШВ & ВСД & ВСД & ВСД & ВСД & ВСД \\
\hline 6. & \multicolumn{7}{|c|}{ Анамнез захворювання (Anamnesis morbi): } \\
\hline a) & $\begin{array}{l}\text { Тривалість } \\
\text { захворювання } \\
\text { (роки) }\end{array}$ & 4 & 1,58 & 0,66 & 5 & 1 & 4,24 \\
\hline б) & $\begin{array}{l}\text { Динаміка } \\
\text { процесу }\end{array}$ & Повільна & Поступова & Різка & Повільна & Поступова & Повільна \\
\hline 7. & \multicolumn{7}{|c|}{ Анамнез життя (Anamnesis vitae): } \\
\hline a) & Спадковість & $\begin{array}{l}\mathrm{He} \\
\text { обтяжена }\end{array}$ & $\begin{array}{l}\mathrm{He} \\
\text { обтяжена }\end{array}$ & Не обтяжена & $\begin{array}{l}\text { Не } \\
\text { обтяжена }\end{array}$ & Не обтяжена & $\begin{array}{l}\mathrm{He} \\
\text { обтяжена }\end{array}$ \\
\hline б) & $\begin{array}{l}\text { Трудове } \\
\text { життя }\end{array}$ & Напружене & Напружене & Напружене & Нормальне & Нормальне & Нормальне \\
\hline в) & $\begin{array}{l}\text { Перенесені } \\
\text { захворювання }\end{array}$ & Коклюш & Немас & Немас & Цистит & Немас & Гастрит \\
\hline г) & $\begin{array}{l}\text { Шкідливі } \\
\text { звички }\end{array}$ & Куріння & Куріння & Відсутні & Відсутні & Відсутні & Відсутні \\
\hline 8. & \multicolumn{7}{|c|}{ Об'єктивне обстеження (Status praesens objectivus) стану шкіри поза вогнищами ураження: } \\
\hline a) & Тургор & Підвищений & Підвищений & Підвищений & Підвищений & Підвищений & Підвищений \\
\hline 6) & $\begin{array}{l}\text { Тип кольору } \\
\text { шкіри }\end{array}$ & 4 & 3 & 3 & 2 & 3 & 1 \\
\hline 9. & \multicolumn{7}{|c|}{ Локальний статус (Statuslocalis): } \\
\hline a) & $\begin{array}{l}\text { Характер } \\
\text { ураження }\end{array}$ & Хронічний & Підгострий & Гострий & Хронічний & Підгострий & Хронічний \\
\hline 6) & $\begin{array}{l}\text { Частина } \\
\text { ділянки } \\
\text { ураження }\end{array}$ & Поодинока & Багато & Багато & Поодинока & Багато & Багато \\
\hline в) & $\begin{array}{l}\text { Локалізація } \\
\text { вогнищ у } \\
\text { ділянках } \\
\text { уражень } \\
\end{array}$ & $\begin{array}{l}\text { Лобна, } \\
\text { тім'яна, } \\
\text { потилична, } \\
\text { скронева } \\
\end{array}$ & Потилична & $\begin{array}{l}\text { Нижня } \\
\text { тім'яна }\end{array}$ & Тім'яна & $\begin{array}{l}\text { Нижня } \\
\text { потилична }\end{array}$ & $\begin{array}{l}\text { Лобна, } \\
\text { тім'яна, } \\
\text { потилична, } \\
\text { скронева }\end{array}$ \\
\hline г) & $\begin{array}{l}\text { Симетричність } \\
\text { ураження }\end{array}$ & Симетричне & Симетричне & Асиметричне & Симетричне & Асиметричне & Симетричне \\
\hline 10. & \multicolumn{7}{|c|}{ Результати трихоскопії тім'яної і потиличної ділянок: } \\
\hline a) & До лікування & $157 / 149$ & $278 / 283$ & $217 / 214$ & $213 / 210$ & $239 / 241$ & $279 / 286$ \\
\hline б) & Після масажу & $311 / 302$ & $310 / 312$ & $305 / 326$ & $306 / 304$ & $299 / 301$ & $323 / 330$ \\
\hline 11. & $\begin{array}{l}\text { Об'сктивні } \\
\text { зміни після } \\
\text { проведеного } \\
\text { лікування } \\
\end{array}$ & Ріст волосся & $\begin{array}{l}\text { Поява } \\
\text { поодиноких } \\
\text { пушкових } \\
\text { волосин } \\
\end{array}$ & Ріст волосся & Ріст волосся & Ріст волосся & $\begin{array}{l}\text { Поява } \\
\text { поодиноких } \\
\text { пушкових } \\
\text { волосин } \\
\end{array}$ \\
\hline 12. & $\begin{array}{l}\text { Суб'єктивний } \\
\text { стан пацієнта } \\
\text { після } \\
\text { процедур }\end{array}$ & $\begin{array}{l}\text { Суттєве } \\
\text { покращення }\end{array}$ & $\begin{array}{l}\text { Суттєве } \\
\text { покращення, } \\
\text { зменшення } \\
\text { нападів } \\
\text { головного } \\
\text { болю }\end{array}$ & $\begin{array}{l}\text { Суттєве } \\
\text { покращення, } \\
\text { зменшення } \\
\text { нападів } \\
\text { головного } \\
\text { болю }\end{array}$ & $\begin{array}{l}\text { Суттєве } \\
\text { покращення }\end{array}$ & $\begin{array}{l}\text { Суттєве } \\
\text { покращення, } \\
\text { зникнення } \\
\text { головного } \\
\text { болю }\end{array}$ & $\begin{array}{l}\text { Суттєве } \\
\text { покращення, } \\
\text { зникнення } \\
\text { головного } \\
\text { болю }\end{array}$ \\
\hline
\end{tabular}


Таблиця 3. Результати обстеження пацієнтів, які пройшли базову терапію у поєднанні з лікувальним масажем ефірними оліями

\begin{tabular}{|c|c|c|c|c|c|c|c|}
\hline 1. & Паціснт & 1 & 2 & 3 & 4 & 5 & 6 \\
\hline 2. & Вік (роки) & 25 & 18 & 25 & 23 & 45 & 61 \\
\hline 3. & Maca (кг) & 57 & 50 & 70 & 53 & 72 & 80 \\
\hline 4. & Зріст (см) & 173 & 167 & 162 & 150 & 175 & 156 \\
\hline 5. & $\begin{array}{l}\text { Супутній } \\
\text { клінічний } \\
\text { діагноз } \\
\end{array}$ & ВСД & ОШВ & ВСД & ВСД & ОШВ & $\mathrm{A} \Gamma$ \\
\hline 6. & \multicolumn{7}{|c|}{ Анамнез захворювання (Anamnesis morbi): } \\
\hline a) & $\begin{array}{l}\text { Тривалість } \\
\text { захворювання } \\
\text { (роки) }\end{array}$ & 7 & 1 & 1,33 & 2 & 0,41 & 5,74 \\
\hline б) & $\begin{array}{l}\text { Динаміка } \\
\text { процесу }\end{array}$ & Повільна & Повільна & Поступова & Поступова & Різка & Поступова \\
\hline 7. & \multicolumn{7}{|c|}{ Анамнез життя (Anamnesis vitae): } \\
\hline a) & Спадковість & Негативна & Негативна & - & Негативна & - & - \\
\hline 6) & $\begin{array}{l}\text { Трудове } \\
\text { життя }\end{array}$ & Напружене & Нормальне & Напружене & Нормальне & Напружене & Відсутне \\
\hline B) & $\begin{array}{l}\text { Перенесені } \\
\text { захворювання }\end{array}$ & ДЖВШ & Цистит & Немає & Гастрит & Немає & Холецистит \\
\hline Г) & $\begin{array}{l}\text { Шкідливі } \\
\text { звички }\end{array}$ & Відсутні & Відсутні & Відсутні & Куріння & Куріння & Відсутні \\
\hline 8. & \multicolumn{7}{|c|}{ Об’сктивне обстеження (Status praesens objectivus) стану шкіри поза вогнищами ураження: } \\
\hline a) & Тургор & Підвищений & Нормальний & Підвищений & Підвищений & Підвищений & Знижений \\
\hline б) & $\begin{array}{l}\text { Тип кольору } \\
\text { шкіри }\end{array}$ & 3 & 2 & 1 & 2 & 3 & 3 \\
\hline 9 & \multicolumn{7}{|c|}{ Локальний статус (Status localis): } \\
\hline a) & $\begin{array}{l}\text { Характер } \\
\text { ураження }\end{array}$ & Хронічний & Хронічний & Підгострий & Підгострий & Гострий & Дистрофічний \\
\hline б) & $\begin{array}{l}\text { Частина } \\
\text { ділянки } \\
\text { ураження }\end{array}$ & Багато & Поодинока & Поодинока & Поодинока & $\begin{array}{l}\text { Тільки одне } \\
\text { вогнище }\end{array}$ & Багато \\
\hline B) & $\begin{array}{l}\text { Локалізація } \\
\text { вогнищ у } \\
\text { ділянках } \\
\text { уражень }\end{array}$ & $\begin{array}{l}\text { Нижня } \\
\text { тім'яна та } \\
\text { верхня } \\
\text { потилична }\end{array}$ & Потилична & $\begin{array}{l}\text { Нижня } \\
\text { тім'яна та } \\
\text { верхня } \\
\text { потилична }\end{array}$ & Тім'яна & Тім'яна & $\begin{array}{l}\text { Тім'яна, } \\
\text { потилична, } \\
\text { скронева }\end{array}$ \\
\hline г) & $\begin{array}{l}\text { Симетричність } \\
\text { ураження }\end{array}$ & Симетричне & Симетричне & Асиметричне & Асиметричне & Асиметричне & Симетричне \\
\hline 10. & \multicolumn{7}{|c|}{ Результати трихоскопії тім'яної та потиличної ділянок: } \\
\hline a) & До лікування & $246 / 234$ & $278 / 283$ & $211 / 246$ & $178 / 162$ & $233 / 254$ & $152 / 150$ \\
\hline б) & $\begin{array}{l}\text { Після масажу } \\
\text { з оліями }\end{array}$ & $312 / 300$ & $310 / 312$ & $321 / 349$ & $315 / 311$ & $319 / 345$ & $320 / 325$ \\
\hline 11. & $\begin{array}{l}\text { Об'єктивні } \\
\text { зміни після } \\
\text { проведеного } \\
\text { лікування } \\
\end{array}$ & $\begin{array}{l}\text { Ріст } \\
\text { волосся }\end{array}$ & Ріст волосся & Ріст волосся & Ріст волосся & Ріст волосся & Ріст волосся \\
\hline 12. & $\begin{array}{l}\text { Суб'єктивний } \\
\text { стан пацієнта } \\
\text { після } \\
\text { процедур }\end{array}$ & $\begin{array}{l}\text { Суттеве } \\
\text { покращення }\end{array}$ & $\begin{array}{l}\text { Суттеве } \\
\text { покращення, } \\
\text { зникнення } \\
\text { головного } \\
\text { болю }\end{array}$ & \begin{tabular}{|l} 
Суттєве \\
покращення, \\
зникнення \\
головного \\
болю
\end{tabular} & $\begin{array}{l}\text { Суттеве } \\
\text { покращення, } \\
\text { зникнення } \\
\text { головного } \\
\text { болю }\end{array}$ & \begin{tabular}{|l} 
Суттєве \\
покращення, \\
зменшення \\
нападів \\
головного \\
болю \\
\end{tabular} & $\begin{array}{l}\text { Суттєве } \\
\text { покращення }\end{array}$ \\
\hline
\end{tabular}


Таблиця 4. Результати розрахунків за показниками віку, маси, зросту і тривалості захворювання для трьох груп пацієнтів

\begin{tabular}{|l|c|c|c|}
\hline \multicolumn{1}{|c|}{ Показник } & Група А & Група Б & Група В \\
\hline Вік (роки) & $34,2 \pm 5,4$ & $34,2 \pm 5,4$ & $32,8 \pm 7,4$ \\
& & $\mathrm{p}_{1}>0,5$ & $\mathrm{p}_{1}>0,5, \mathrm{p}_{2}>0,5$ \\
\hline Маса (кг) & $68,8 \pm 6,0$ & $60,2 \pm 6,0$ & $63,7 \pm 5,0$ \\
& & $\mathrm{p}_{1}>0,1$ & $\mathrm{p}_{1}>0,5, \mathrm{p}_{2}>0,5$ \\
\hline Зріст (см) & $164,5 \pm 2,6$ & $159,8 \pm 4,8$ & $163,8 \pm 4,4$ \\
& & $\mathrm{p}_{1}>0,1$ & $\mathrm{p}_{1}>0,5, \mathrm{p}_{2}>0,5$ \\
\hline Тривалість захворювання & $2,68 \pm 0,9$ & $2,75 \pm 0,8$ & $2,79 \pm 1,1$ \\
(роки) & & $\mathrm{p}_{1}>0,5$ & $\mathrm{p}_{1}>0,5, \mathrm{p}_{2}>0,5$ \\
\hline
\end{tabular}

Примітка. У цій і наступній таблицях $\mathrm{p}_{1}$ - вірогідність відмінностей відносно групи А, $\mathrm{p}_{2}$ - вірогідність відмінностей відносно групиБ.

Таблиця 5. Показники трихоскопії до та після проведення лікүвання

\begin{tabular}{|c|c|c|c|}
\hline Показник & Група А & Група Б & Група В \\
\hline Тім'яна ділянка до лікування (шт/см²) & $214,8 \pm 15,8$ & $230,5 \pm 20,6$ & $216,3 \pm 20,6$ \\
\hline Тім'яна ділянка після лікування (шт/см²) & $227,2 \pm 15,4$ & $\begin{array}{c}309,0 \pm 3,6 \\
\mathrm{p}_{1}>0,01\end{array}$ & $\begin{array}{c}316,2 \pm 2,0 \\
\mathrm{p}_{1}>0,01, \mathrm{p}_{2}>0,1\end{array}$ \\
\hline Потилична ділянка до лікування (шт/см²) & $226,5 \pm 14,9$ & $230,5 \pm 23,0$ & $221,5 \pm 23,9$ \\
\hline Потилична ділянка після лікування (шт/см²) & $239,3 \pm 13,9$ & $\begin{array}{l}312,5 \pm 5,7 \\
\mathbf{p}_{1}>0,005\end{array}$ & $\begin{array}{c}323,7 \pm 8,8 \\
\mathrm{p}_{1}>0,005, \mathrm{p}_{2}>0,1\end{array}$ \\
\hline 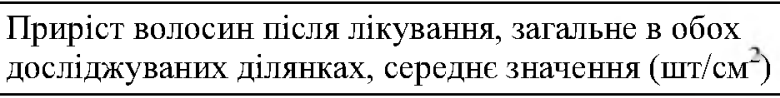 & $12,6 \pm 0,7$ & $\begin{array}{c}80,25 \pm 13,2 \\
\mathrm{p}_{1}>0,001\end{array}$ & $\begin{array}{c}101,0 \pm 13,8 \\
\mathrm{p}_{1}>0,001, \mathrm{p}_{2}>0,05\end{array}$ \\
\hline Приріст волосин у тім'яній ділянщі після лікування (\%) & 5,7 & 34,1 & 46,2 \\
\hline Приріст волосин у тім'яній ділянці після лікування (\%) & 5,7 & 35,5 & 46,1 \\
\hline $\begin{array}{l}\text { Приріст волосин після лікування, загальне середнс } \\
\text { значення (\%) }\end{array}$ & 5,7 & 34,8 & 46,15 \\
\hline
\end{tabular}

Висновки. В даній статті досліджено вплив лікувального масажу волосистої частини голови 3 ефірними оліями та без них на ріст волосся у пацієнтів з алопецією. Було відібрано три групи пацієнтів, двом групам з яких проводився лікувальний масаж волосистої частини голови та одній групімасаж волосистої частини голови з ефірними оліями. За результатами проведених експериментальних досліджень та їх порівняльного аналізу встановлено, що лікувальний масаж волосистої частини голови дає стійкий лікувальний ефект, який

\section{ЛІТЕРАТУРА}

1. Современные подходык лечению дифффузнойалопеции у пациентов разных возрастных групп / 3. 3. Кадашова, В. А. Ли, Г. И. Суколин, В.Н. Шабалин // Terra Medica. - 2013. - № 2. - C. 35-38.

2. Менг Ф. М. Современные аспекты распространенности заболеваний волос среди населения / Ф. М. Менг, ЮО.В.Олейников / / Пробл. дерматовенерол. и мед. косметол. на совр. этапе. - Владивосток, 2005. - С. 167-170. можна оцінити в прирості волосин на 29,1\% і підвищенні до 40,5 \%, за умови використання ефрірних олій, що стимулюють ріст волосся порівняно з базовою терапією. Встановлено, що у пацієнтів, у яких алопеція поєднувалася із супутніми захворюваннями, що супроводжуються головним болем, застосування лікувального масажу приводило до зменшення випадків появи головного болю, а у деяких пацієнтів і до повного його зникнення після проходження курсу масажу волосистої частини голови.

3. Качанов О. Є. Методики застосування лікувального масажу з використанням ефірних олій у пацієнтів 3 алопецією / О. Є. Качанов, О. М. Олещук // Медсестринство. - 2014. - № 1. - С. 22-24.

4. Савчак В. Медсестринство в дерматовенерології / В. Савчак, М. Ковальчук / / Тернопіль : Укрмедкнига, 2003. $-170 \mathrm{c}$. 